\title{
NinguÉM TE LÊ: UM POEMA ANÔNIMO de Augusto de Campos
}

NOBODY READS YOU: AN ANONYMOUS POEM

BY AUGusto de CAMPOS

Thiago Castañon

ORCID 0000-0002-4577-6254

Universidade Federal do Rio de Janeiro

Rio de Janeiro, Brasil

\begin{abstract}
Resumo
Visando retirar do ostracismo um poema que ainda não foi lido como poema por ninguém na crítica brasileira, este ensaio procura dispor algumas reflexóes em torno de oútis, que abre o livro Não, de Augusto de Campos. Partindo da única exceção de Gonzalo Aguilar, que lhe dedica dois parágrafos valiosos, desenvolve-se a hipótese de que as datas desmedidas que acompanham o título do poema permitem lê-lo como síntese da poética do autor. Num estudo preliminar das relaçóes entre poesia e fotografia, em diálogo com formulaçóes de Benjamin, Eisenstein e Fenollosa sobre a montagem cinematográfica e a técnica do ideograma, destaca-se a complexidade envolvida nesse "poema de uma palavra só" sobreposta à imagem de sombras na grama, cuja sintaxe supóe uma rede intrincada de conexôes entre o visível e o legível, o português e o grego, a poesia, as artes visuais e outros poemas ao longo da história, com que entra numa constelação sincrônica.
\end{abstract}

Palavras-chave: Poesia visual, Fotografia, Montagem, Ideograma, Ato de escrita

\section{Abstract}

Aiming to remove from ostracism a poem that has not yet been read as a poem by anyone in Brazilian criticism, this essay seeks to provide some reflections around oútis, the opening poem in Augusto de Campos' book Não. Starting from the only exception of Gonzalo Aguilar, who dedicates two valuable paragraphs to this poem, this paper puts forward the hypothesis that the excessively long date range appearing under the poem's title leads us to read it as a synthesis of the author's poetics. In a preliminary study of the relationship between poetry and photography, in dialogue with formulations by Benjamin, Eisenstein

\section{Resumen}

Con el objetivo de sacar del ostracismo un poema que aún no ha sido leído como un poema por nadie en la crítica brasileńa, este ensayo busca proporcionar algunas reflexiones sobre oútis, que abre el libro Não, de Augusto de Campos. Partiendo de la única excepción de Gonzalo Aguilar, quien le dedica dos valiosos párrafos, se desarrolla la hipótesis de que las fechas excesivas que acompañan el titulo del poema permiten leerlo como una síntesis de la poética del autor. En un estudio preliminar de la relación entre poesía y fotografía, en diálogo con formulaciones de Benjamin, Eisenstein y Fenollosa sobre el montaje cinematográfico y la técnica 
and Fenollosa on the cinematographic montage and the ideogram technique, we highlight the complexity involved in this "one-word poem" superimposed on the image of shadows on the grass, whose syntax assumes an intricate network of connections between the visible and the readable, Portuguese and Greek, poetry, visual arts and other poems throughout history, with which it enters in a synchronic constellation.

Keywords: Visual poetry, Photography, Montage, Ideogram, Act of writing del ideograma, nosotros destacamos la complejidad involucrada en este "poema de una palabra" superpuesta a la imagen de sombras en la hierba, cuya sintaxis supone una intrincada red de conexiones entre lo visible y lo legible, el portugués y el griego, la poesía, las artes visuales y otros poemas a lo largo de la historia, con los cuales entra en una constelación sincrónica.

Palabras claves: Poesia visual, Fotografia, Montaje, Ideograma, Acto de escritura

ah mallarmé... ninguém te lê... tudo existe pra acabar em tv Augusto de Campos, tvgrama I (1988)

Já se disse que "o analfabeto do futuro não será quem não sabe ler, e sim quem não sabe fotografar". Mas um fotógrafo que não sabe ler suas próprias imagens não é pior do que um analfabeto? Walter Benjamin, Pequena história da fotografia

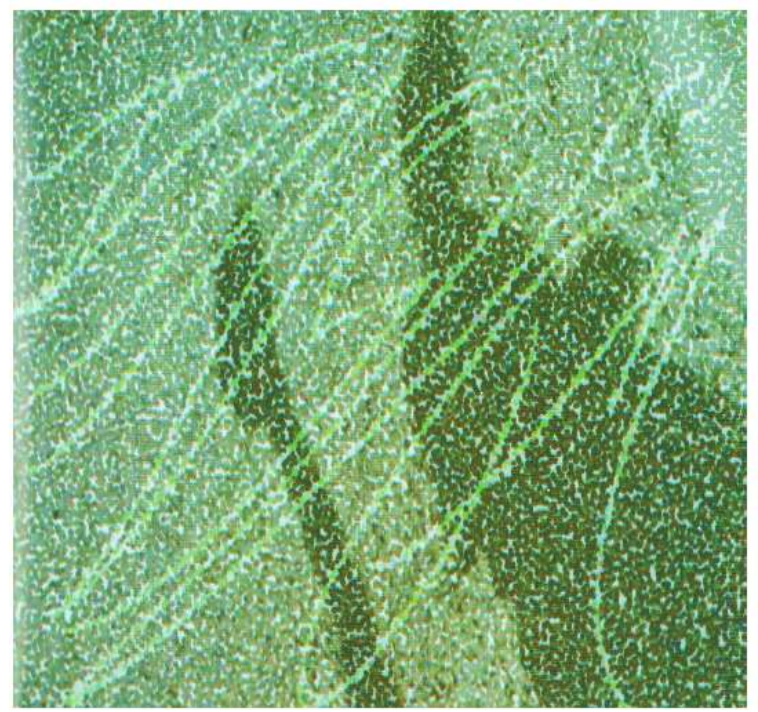

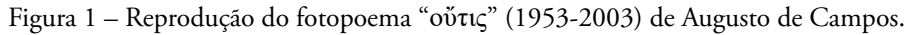
Fonte: CAMPOS, Augusto de. Não. São Paulo: Perspectiva, 2008, p. 13. 
No único texto que menciona o poema de abertura do livro Não (2003) na bibliografia existente sobre Augusto de Campos, incluído no catálogo da exposição Poesia concreta: o projeto verbivocovisual, organizado por João Bandeira e Lenora de Barros, em 2007, Gonzalo Aguilar chama atenção para as datas desmedidas que acompanham o título grego da peça: oü $\iota \varsigma$ (19532003). A discrepância da informação técnica quanto à obra correspondente provoca, no mínimo, estranheza: que significa dizer que um poema de uma palavra só tenha levado 50 anos?!

Sugerindo um trabalho infatigável de cinco décadas, engajado em valores de perfeição e acabamento, em contraste com a aparente pobreza do resultado, a expectativa suscitada de uma grande obra-prima é claramente frustrada pelo poema. Dessa contradição performativa digna de um conto de Borges, o crítico argentino infere que, desde que oútis "não dá a sensação de ter levado 50 anos", o leitor vê-se justificado em indagar se as datas não poderiam assumir outra significação. Conforme a segunda alternativa, para o intérprete, a razão da desmedida não estaria no tempo necessário à composição do poema, mas na sugestáo de que fosse lido como um "pano de fundo da poética de Augusto" (2008: 181), isto é, como tendo relação com cinco décadas da trajetória poética do autor, completadas em 2003, a contar de seus primeiros poemas visuais, iniciados com a série Poetamenos, em 1953.

Em reforço dessa proposta de leitura, acrescenta-se o fato de que no mesmo ano em que Aguilar formula sua hipótese, Augusto de Campos trabalhava numa segunda versão do poema, transposto para o formato videoclipe. Embora tenha sido produzido em 2007, o clip-poema "ninguém" só seria apresentado a público em 2016, na exposição Rever, com acréscimos e modificaçôes que confirmam largamente a intuição do leitor portenho, como atesta uma breve comparação entre as duas versōes.

$\mathrm{Na}$ versão publicada no livro $N a ̃ o$, o poema oútis se apresenta composto de duas camadas distintas, formando uma única superfície monocromática, pontilhada em tons de verde. A primeira, de dominância visual, em tons de verde escuro, sugere a imagem de sombras na grama, discretamente diferenciada como segundo plano. A ela se acrescenta, em primeiro plano, uma camada de dominância verbal, em tons de verde claro, com letras garrafais manuscritas em caracteres maiúsculos preenchendo toda a grande página de $23 \times 23$, formando a palavra NINGUÉM, grafada numa caligrafia propositalmente difícil que a torna menos reconhecível à primeira vista, sugerindo uma improvável palavra escrita na grama, tão efêmera quanto os "Versos escritos n'água" de Manuel Bandeira ou as palavras inscritas no sepulcro de Keats: "Here lies One Whose Name was writ In Water". 
Antecipando o argumento a ser desenvolvido, duas observaçóes preliminares.

1. Antes de saber o que significa o título, a evocação de um nome grego estabelece uma moldura prévia capaz de produzir efeitos de leitura. Enquanto elemento presente nas duas séries, a "grama" cobrindo tudo, palavra e imagem, sugere a possibilidade de tomá-la como eixo que articula os dois planos, identificados numa escrita dupla, verbal e visual, conforme o correspondente grego grámma, que reúne os sentidos de pintura e escritura, literalmente: "o que se desenha" (pintura, quadro, figura) e "o que se grava" (sinal gráfico, algarismo, letra). Soma-se a isso a predileção de Augusto de Campos por palavras compostas com o sufixo "-grama", usado como índice de escrita visual em expressōes como "profilograma", "morfograma", "stelegrama", "tvgrama”, "criptocardiograma", "lobograma” etc., cunhadas para nomear seus próprios poemas, que, antes de serem chamados de "poesia concreta" (1955), recebiam a designação genérica de "ideogramas" (em 1953, ano de Poetamenos e do início de oútis).

2. Nota-se também um efeito de cacografia, recorrente nos poemas do autor, pelo qual o olhar é forçado a se concentrar previamente na diferenciação e reconhecimento das letras (grámmata) do poema, antes mesmo de "lê-lo", de modo a atravessar sua camada verbal como se os signos fossem transparentes aos significados. Produzindo um estado de atenção que se prolonga durante a leitura, a resistência visual da letra e do escrito implica uma ativação dos sentidos para cada forma gráfica, som, morfema, efeitos de eco (por homonímia e homofonia) e de hipograma (palavras dentro das palavras), a fim de apreender o momento em que cada harmônico semântico, cada rastro etimológico e cada citação literária vem assumir uma importância inesperada, sem que nenhuma ocupe a posição de centro, abrindo um campo de possibilidades de leitura e multileitura que sempre pode fracassar. Possibilidade de fracasso que define o espaço de jogo do poema.

Passando à segunda versão, no minivideoclipe de 16 segundos a estruturação dupla, poética e pictórica, se torna mais evidente pela decomposição dos planos simultâneos em sequências independentes de fotogramas, que se sobrepóem diante dos olhos do espectador por movimentos de corte, fade in e fade out, explicitando, por alternância e justaposição, o princípio de montagem cinematográfica subjacente à versão impressa. A obra é acrescida de som e movimento, de modo que às duas camadas anteriores (verbal e visual) sobrepóe-se uma terceira (vocal e sonora), em que podemos ouvir a oralização da primeira estrofe de "O rei menos o reino", de 1950, acompanhada de um ruído que se interrompe na palavra "deserto", deixando apenas a voz do poeta que pronuncia o quarto verso contra um fundo de silêncio tornado subitamente "audível": 
Onde a Angústia, roendo um não de pedra,

Digere sem saber o braço esquerdo,

Me situo lavrando esse deserto,

De areia, areia, arena, céu e areia.

Repare-se que o "eu" do poeta está presente em todos os planos: no som de sua voz, na caligrafia da escrita, semelhante à assinatura de um nome próprio, e, segundo esse paralelismo, podemos supor que também esteja na imagem de sua sombra. No entanto, náo vemos o rosto, nem lemos o nome de um sujeito identificável, que a voz do poema apresenta com um sinal de menos. Será suficiente destacar duas metamorfoses que a metáfora do "escrito na grama" recebe aqui. Na primeira, a palavra "ninguém" aparece "escrita numa tela de TV", sobre uma estática de fundo granulada em preto e branco, simultaneamente à escuta da expressão "me situo", vinculando o poema ao presente tecnológico e midiático. $\mathrm{Na}$ segunda, a palavra retorna sobre um fundo texturizado em tons de branco como um "escrito na areia", sob influxo do quarto verso, que estabelece uma relaçáo dessa variante do texto "branco sobre branco" com seus equivalentes poético e pictórico, a página em branco de Mallarmé e a tela em branco de Maliêvitch, aproximados de um valeryano "deserto da consciência", evocado nos versos líricos de juventude.
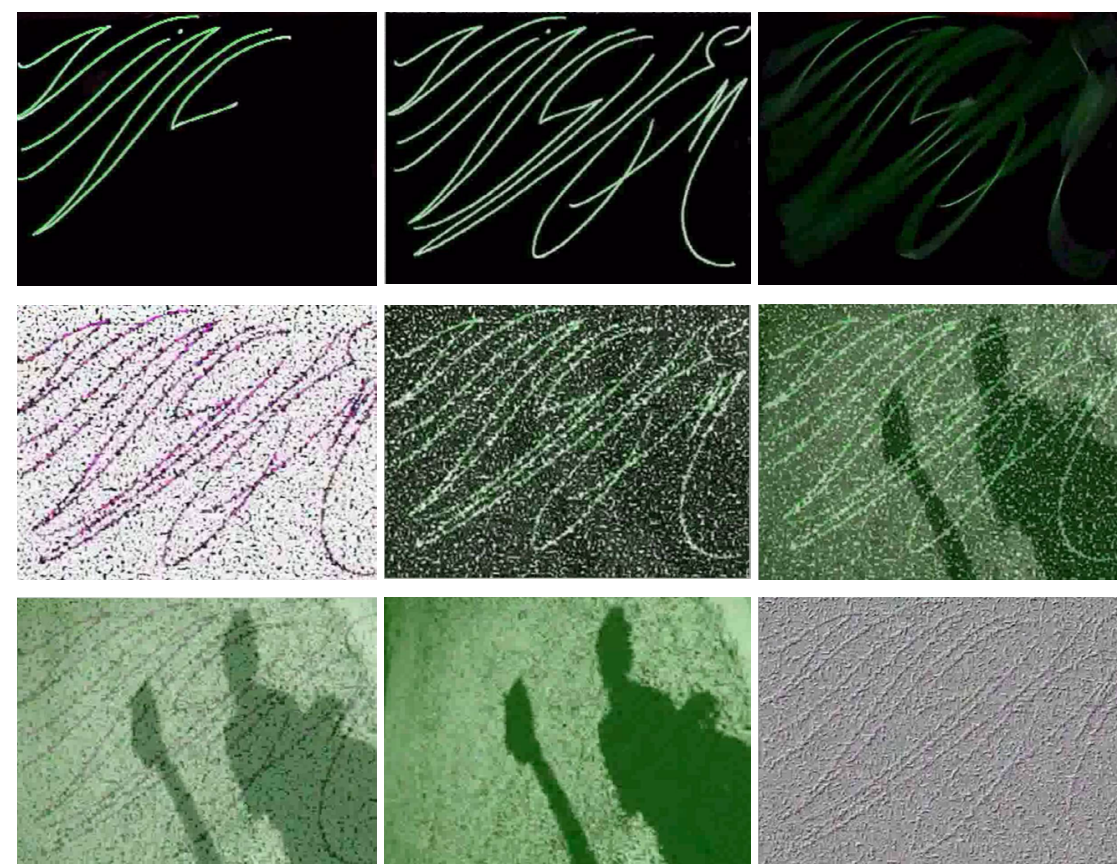

Figura 2 - Reprodução de 9 fotogramas do videopoema "Ninguém" (2007) de Augusto de Campos. Printscreens selecionados a partir do arquivo original em formato mp4.

Fonte: Arquivo pessoal de Augusto de Campos. A obra exibida pela primeira vez em 2016 na exposiçáo

"Rever" ainda náo se encontra disponível em suporte físico ou eletrônico. Imagens cedidas pelo autor. 
Embora contenha mais elementos e associaçóes que a versão impressa, o videoclipe não torna a obra mais complexa, senão que explicita complexidade já presente no papel. Assim, a citação de $O$ rei menos o reino, em que "o estatuto do sujeito lírico já era bastante problemático" (STERZI, 2004, p. 105), cujo primeiro verso introduz a imagem de um "não esfíngico [que] se transforma em poema" (SISCAR, 2006, p. 120), relacionando o miniclipe com o livro de estreia do autor, reforça a suspeita sobre a possibilidade de ler oútis como uma síntese de traços que atravessam a poética de Augusto desde seus poemas pré-concretos até os mais recentes concebidos em meio eletrônico e apresentados em performances audiovisuais.

\section{Montagem e ideograma}

Sobre os recursos empregados e etapas de realização do poema, propositalmente omitidos na ficha técnica do livro, Augusto de Campos nos forneceu alguns esclarecimentos por e-mail. ${ }^{1}$ Como explica, com riqueza de detalhes, a data de início refere-se ao ano da pequena fotografia em $6 \times 6$, tirada com uma máquina Firstflex, "prima pobre da famosa Rolleyflex", enquadrando a sombra do poeta ao lado de um poste de iluminação, sobre a grama do parque da Água Branca, no bairro das Perdizes. "A ideia surgiu na hora", recorda, não havendo nenhuma intenção literária prévia ao recorte inusitado de sombras na grama, apenas a pretensão de tirar uma "fotografia artística", com um enquadramento que qualificava, àquela altura, de "eisensteiniano". Segue uma reprodução da fotografia de 1953, sem edição, na posição original em que foi batida:

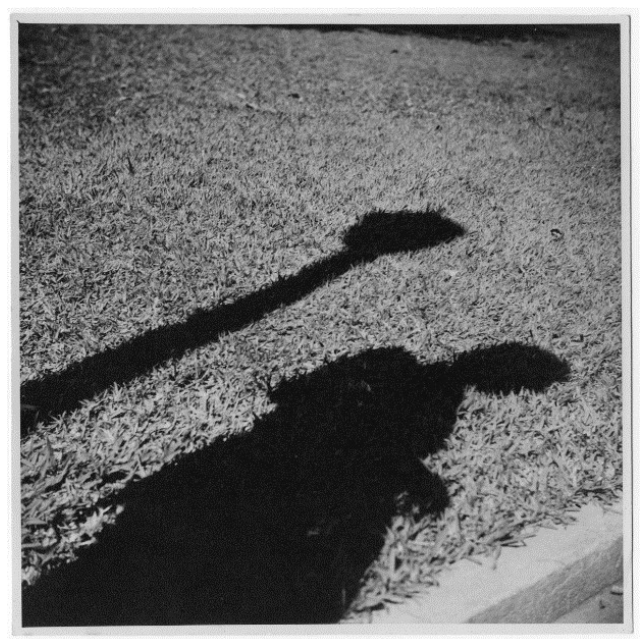

Figura 3 - "Augusto Sombra 1953". Autorretrato de Augusto de Campos. Registro feito no parque da Água Branca, bairro das Perdizes, São Paulo, em 1953. Fonte: Arquivo pessoal do autor. Imagens cedidas pelo autor.

1 Correspondência de $14.7 .19,4.8 .19$ e 12.11 .19 . 
Como não caberia tratar da história da fotografia como forma de arte no Brasil, o breve parêntese a seguir visa introduzir apenas um contraste pontual entre o uso da fotografia pelo poeta de vanguarda dos anos $1950 \mathrm{e}$ um de seus precursores dos anos 1920, a partir de uma coincidência notável. Poucos saberão, mas além de poeta e musicólogo, Mário de Andrade também foi pioneiro da fotografia modernista no Brasil. Como a linguagem fotográfica não foi contemplada pela Semana de 22 e suas comemorações habituais, esta permaneceu uma face menos conhecida do poeta, que, entre 1923 e 1936, colecionou cerca de 1500 fotos. Segundo os curadores da exposiçáo Mário fotógrafo, realizada em 2019 pela Casa Mário de Andrade, suas fotografias "registram patrimônios históricos, crianças, trabalhadores e imagens que revelam suas preocupaçóes estéticas e experiências de revelação". Numa declaração feita em 1929, o poeta, que chamava sua máquina de "codaque" e inventou o verbo "fotar", reflete sobre o caráter artístico da fotografia em chave modernista:

Aquilo em que a fotografia artística se eleva sobre a puramente documental, reside não na máquina ou na luz, como imaginam confusionistamente os manipuladores de truques fotográficos ou os "fotografadores" de eternos crepúsculos românticos, mas na criação humana do artista. Enfim, há que ter esse dom especial de apanhar a poesia do real. ${ }^{2}$

Entre os instantâneos de Mário, encontram-se experimentos curiosos como seu autorretrato em sombra, publicado em $A$ imagem de Mário fotobiografia de Mário de Andrade (1998). A título de contraste, compare-se a fotografia de Augusto com a imagem da sombra de Mário sobre a grama da fazenda de Tarsila do Amaral, em Santa Teresa do Alto, que o poeta "autofotou" em $1^{\circ}$ de janeiro de 1927.3

Na película de Mário, a ênfase cai sobre a "sombra", em contraste com a expectativa de um "autorretrato", como sugerem os contornos mais definidos, o ângulo tradicional do enquadramento e o título explícito: "Sombra minha”. Em nenhum momento a fotografia ressalta a importância do signo grama, que aparece esparsa entre folhas, galhos e espaços de terra. Inversamente, a presença da segunda sombra em oútis, à primeira vista, desprovida de valor semântico, de imediato diminui a centralidade do eu, que não preenche sozinho o campo visual, nem aparece imóvel e de frente, mas se introduz na cena de modo oblíquo. Ao contrário do poeta modernista, também não parece que o "ninguém" da fotografia olhe para sua própria pose, mas, em vez de se automirar, volta-se para outro lado, onde sua sombra não está. $\mathrm{Na}$

$2 \mathrm{http} / / /$ casamariodeandrade.org.br/noticia-casa-mario-de-andrade-inaugura-exposicao

3 Devo a lembrança da fotografia de Mário de Andrade a Júlio Castañon. 


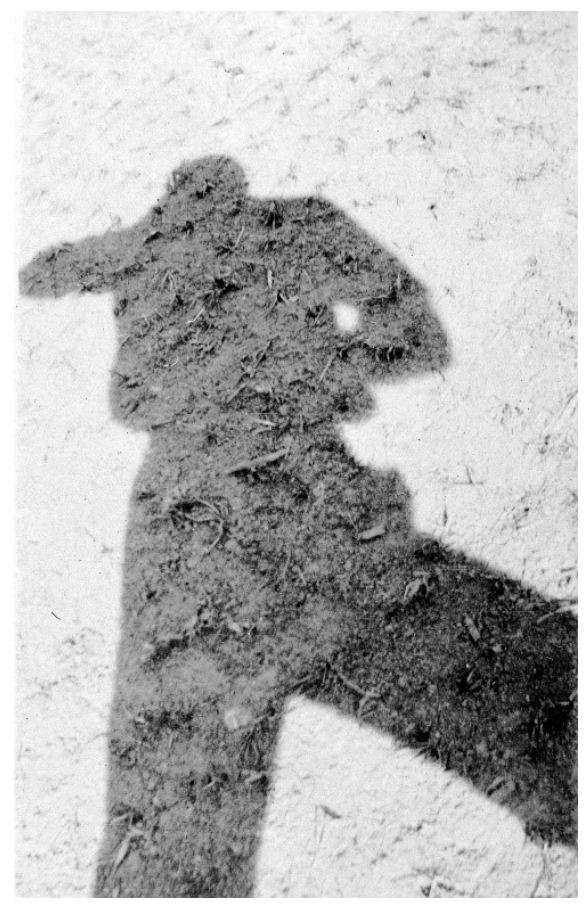

Figura 4 - "Sombra minha”. Autorretrato de Mário de Andrade. Registro feito no sítio de Tarsila do Amaral, em Santa Teresa do Alto, em $1^{\circ}$ de janeiro de 1927.

Fonte: ANDRADE, Mário de. A imagem de Mário - fotobiografia de Mário de Andrade.

Rio de Janeiro: Alumbramento, 1998.

verdade, somente a foto revela o que o poema não permite ver muito bem: uma mancha verde clara, esmaecida no alto da página, sobre o acento agudo do E, que a foto permite identificar com a quina de pedra de um meio-fio enquadrada por Augusto, que assinala a presença do pavimento asfaltado onde o fotografado está pisando - e, através desse fragmento metonímico, o pano de fundo da cidade onde o poeta caminha entre anônimos. $\mathrm{O}$ oposto da paisagem bucólica do sítio e do círculo privado que a legenda associa ao autorretrato anônimo de Mário.

Sendo as duas imagens da sombra na grama aparentemente banais, e tendo os dois poetas o propósito declarado de tirar uma foto artística, o que as distinguiria de um registro meramente afetivo-documental? Nesse sentido, vale lembrar o que W. Benjamin anota sobre o caráter da fotografia e do cinema enquanto obras de arte: "fotografar um quadro é um modo de reprodução; fotografar num estúdio um acontecimento fictício é outro. No primeiro caso, o objeto reproduzido é uma obra de arte, e a reproduçáo não o é". No segundo caso, "o objeto reproduzido não é mais uma obra de arte, 
e a reprodução não o é tampouco [...]. Na melhor das hipóteses, a obra de arte surge através da montagem, na qual cada fragmento é a reprodução de um acontecimento que nem constitui em si uma obra de arte, nem engendra uma obra de arte ao ser filmado" (1996: 177-8, grifo meu).

No caso de oútis, para constituir uma fotografia "artística", seria preciso que a imagem já contivesse um princípio interno de montagem, anterior à montagem propriamente dita. Eisenstein chama de enquadramento a transposição para o fotograma do princípio da montagem entre fotogramas e sequências de fotogramas, entendido como "conflito dentro da composição", manifestando-se por tensôes de direçôes gráficas (linhas estáticas ou dinâmicas), de escalas, volumes, massas, profundidades e diferentes intensidades de luz. Desse modo, "considerar a composição (enquadramento) como um caso, por assim dizer, particular, molecular de montagem, torna possível a aplicação direta da prática da montagem à teoria da tomada (plano)" (2000:161).

Começando pela lente de uma objetiva portátil que converte a cidade inteira em um "parque gráfico" à disposiçáo do poeta visual, a primeira peça de oútis tem como ponto de partida um excurso do poeta (literalmente, durante um passeio) no domínio das artes gráficas, motivando a escolha de um ângulo, uma luz ("sol a pino") e uma posição dos elementos no espaço. Isso náo significa, entretanto, que o impulso inicial do poema náo tivesse partido de um lastro verbal ou uma pulsão escritural, como poderia dar a entender a declaraçáo de ausência de intenção prévia.

Como assinala a preferência pelo significante visual "grama", à medida que o fotograma dobra-se sobre si mesmo, comunicando literalmente uma "foto de gramas", pode-se aventar a hipótese de que a foto já surge, desde o início, sobredeterminada pelo cruzamento de idiomas presentes na palavra fotografia (do grego photo-gráphein), que o enquadramento decompóe em signos de luz (phôs) e escrita (grámma). De modo que o signo "luz", implícito nas "sombras", sublinha a importância da "grama" em que se projeta. Desintegrando o acontecimento fotográfico em diversos planos e recompondo, via montagem, a ideia prismática de um "escrito com luz" contido na palavra fotografia, obtém-se uma espécie de "ideograma sem palavras” em que a etimologia latente dos signos visuais permanece constantemente à vista durante o processo metafórico. Do que se conclui que a técnica de montagem da fotografia de Augusto situa oútis no extremo oposto da pretensão de Mário de captar uma suposta "poesia do real".

Vale lembrar a hipótese de um caso-limite imaginado por Haroldo de Campos em 1958, a partir da técnica ideográfica proposta por Fenollosa e aprimorada por Eisenstein. Referindo-se ao princípio formulado pelo sinólogo de que "neste processo de compor, duas coisas conjugadas náo produzem uma terceira, mas sugerem uma relação entre ambas", o poeta infere num salto: 
compreende-se daí que "um ideograma isolado pode ser [...] um verdadeiro poema completo" (1977, p. 56). O exemplo citado da palavra-montagem silvamoonlake, de James Joyce, fundindo as ideias de "bosque (latim, silva) + lua + lago, além da nuance sonora silver (prateada)", que teria levado Louis Gillet a chamá-la de "um pequeno poema completo como um hai cai japonês" (id., p. 58), não se apresenta, entretanto, como tal, mas como parte de um poema, cujo todo seria o próprio Finnegans Wake.

Embora possamos citar inúmeros "poemas de uma palavra só" na obra de Augusto de Campos, ${ }^{4}$ o próprio Haroldo não viria a produzir poemas desse tipo. Antecipando apenas sua possibilidade teórica (como Schlegel fizera com a ideia de "poesia universal progressiva"), de que uma palavra só possa constituir um poema inteiro em circunstâncias adequadas de aglutinação, justaposição e fragmentação, Haroldo retoma novamente o argumento em ensaio posterior, de 1964. Após citar o exemplo da palavra "sonho", yumê 夢 em japonês, formada pela superposição de quatro ideogramas: "vegetação crescendo + rede de pesca + cobertura + sol-pôr", o poeta-teórico observa que este único vocábulo oferece à imaginação poética "um verdadeiro diorama de estratos metafóricos mantidos eventualmente em estado de latência sob a pátina do tempo e os amortecedores do cotidiano" (1977: 64, grifo meu). Seja fazendo vibrar camadas de harmônicos e estratos metafóricos adormecidos "no leito geológico da língua” ou permitindo ao poeta escolher palavras em que um único harmônico dominante vem colorir todos os planos da significação, o próprio poema assim concebido se converteria, nas palavras de Haroldo, numa "espécie de objetiva portátil". No entanto, novamente, o exemplo não é um poema, mas uma mot-monnaie (palavra-moeda) de uso corrente, cuja efígie metafórica se apaga no dia a dia das trocas verbais.

No caso de oútis, a duplicaçáo interna da fotografia (simultaneamente como meio e mensagem), revela uma gramatura subjacente que recorta o significante visual em signos bivocais. Se a composição efetiva do poema corresponde apenas à data final de 2003, a foto de 1953 já possui uma dimensão verbal dupla (grego-português), a ser reativada posteriormente. Mas somente meio século depois Augusto retornaria à imagem para repropô-la como poema efetivo, dessa vez por um segundo procedimento de montagem, com sobreposiçáo do texto NINGUÉM à fotografia. Sendo a foto original em preto e branco, a obra foi finalizada com a aplicação de filtros digitais, utilizando

4 Uma simples enumeração basta para atestar a constância do procedimento radicalizador das formas mínimas, moleculares, de poesia no trabalho de Augusto: "vida" (1957) e "pluvial" (1957), da série Ovonovelo, "cidade” (1963), "acaso" (1963), "luxo (1965)”, os poemas “nada”, "cicatristeza”, "oeilfeujeu”, "pressauro”, "infin” e "rever”, da série Equivocábulos (1970), “viva vaia” (1972) e "código” (1973), todos publicados em Viva vaia (1979); "poema bomba (1987)”, em Despoesia (1994); "criptocardiograma” (1996), “desespelho” (2000) e oútis (1953-2003), em Não (2004); e “humano” (2014), em Outro (2015). 
QuickTime e Photoshop para (re)introduzir a cor verde e a granulação pontilhada da imagem.

De modo que a "única palavra" do poema, aparentemente sem sintaxe, difere de antemáo de uma palavra simplesmente solta na página, na medida em que esta é uma "página preparada" (análoga do "piano preparado" de John Cage) e sua grafia manuscrita adquire valor icônico num processo de montagem em que tudo se torna "hieróglifo necessário", como diria Schlegel. Em vez de evocar aleatoriamente uma metafórica do anonimato e da insignificância (como a palavra "terra" sozinha evocaria toda uma geórgica), a palavra temática "ninguém" aparece triangulada pela relação com a página pictografada e o título grego. Página e título elevados a moldura no lugar do verso e da estrofe. ${ }^{5}$ Assim como os fenômenos tradicionais de rima, assonância e aliteração são menos abolidos que transformados, deslocados, pela paronomásia intersemiótica, entendida como "rima" entre palavra e imagem.

No intervalo que separa a fotografia (1953) do fotopoema (2003), portanto, não houve versões intermediárias. $\mathrm{O}$ poema efetivo nem foi feito, refeito ou perfeito ao longo de cinquenta anos, nem produzido de um só golpe, mas precisamente elaborado em dois tempos, com um intervalo abismal de cinco décadas separando dois atos de inscrição poética, um aos 22 , outro aos 72 anos. Se o videopoema (2007) o reinscreve pela terceira vez, quatro anos depois, trata-se, bem entendido, de um gesto de "finalização" que reafirma o inacabamento estrutural do poema no momento em que atinge sua plena verbivocovisualidade, já que a terceira camada se acrescenta ao modo de suplemento, desdobrando o que está contido nas outras duas, na "poesia silenciosa" da imagem e na "pintura falante" do texto.

As anotaçóes anteriores já serão suficientes para ensaiarmos um passo menos descritivo. Começando pela proposta de leitura da camada visual de oútis, não pretendemos mais que retirar o poema do ostracismo, demonstrando o acerto da intuição de Gonzalo Aguilar.

Sombra, grama e luz

Os tons de verde escuro sugerem a figura facilmente reconhecível de sombras na grama, mas essa facilidade de leitura logo se complica, pois a indeterminação dos contornos deformados opóe resistência ao reconhecimento dos supostos referentes, que apreendemos, a princípio, apenas como "algo" e "alguém”. Arriscando a conversão do quadro num teste projetivo de Roscharch, poderíamos imaginar que a sombra da esquerda, com uma haste fina e

5 Conforme antecipa Mallarmé no prefácio a Un coup de dés: "Página: esta agora servindo de unidade como alhures o Verso" (1974, p. 151). 
arredondada na ponta, se assemelha a um palito de fósforo ou uma placa de trânsito. Estas associaçôes, no entanto, são logo postas em dúvida pela proporção (do fósforo comparado a uma pessoa) e pelo contexto (de um sinal de trânsito perdido no gramado), ainda que o primeiro possa remeter à raiz grega phôs, relacionada ao campo semântico de oútis, e o segundo, enquanto semeîon, também pudesse ser aproximado do poema popcreto sem palavras "olho por olho" (1964), composto de fotografias de olhos recortados de jornais e revistas, formando uma pirâmide cujo topo aponta para o sinal geral de perigo - um dos primeiros poemas fotomontagens de Augusto. ${ }^{6}$ De toda forma, ambos se mantêm no âmbito de ressonância de oútis, inclusive na medida em que certas placas de sinalização de rua, compostas de lâmpadas elétricas, operam com uma notação de pontos acesos e apagados, como o que o poeta utilizou na tipografia de "quasar" (1972), projetado no painel luminoso do Anhangabaú, em 1982, no projeto Arte Acesa, organizado por Julio Plaza.

Por outro lado, a semelhança dessa figura da esquerda com um poste de iluminação apagado, que não ilumina, mas escurece, fazendo(-se) sombra sobre a grama, sugere, nessa conjunção, a área verde de um espaço público onde alguém, cuja identidade desconhecemos, passa anonimamente, marcando um momento efêmero, transitório, e um lugar de impermanência e passagem, conforme indica a sombra da direita, ocultando um vulto solitário, com a cabeça inclinada para frente, como quem olha para o chão; ou para dentro, como se diz de alguém que está metaforicamente "ausente".

Apesar da maior verossimilhança alcançada por essa leitura, não vemos o poste sem luz, nem a pessoa invisível que passa breve como um vulto, mas somente suas sombras, que nada são. Como o lobo que só sabe pensar sempre a mesma coisa: ovelha, ovelha, ovelha, na intradução de Peire Vidal (lobograma) incluída em $N a ̃ o$, dir-se-ia que o olho-câmera do poeta só enxerga: palavras, palavras, palavras. Ou melhor, como Bandeira, que só via o beco, Augusto poderia dizer: tudo o que vejo é grama, escrita.

Conforme sugere seu livro mais recente, Outro (2015), no poemaadendo "deserrata" (2013): "onde se lê leia-se leia-se vê", pode-se propor uma operação semelhante, com a diferença de que oútis supóe, desde o título, uma aproximação bilíngue. Assim, onde se vê "sombra", leia-se: não apenas skiás, em grego, mas os estratos metafóricos dessa palavra, associada, nos

6 O uso de fotomontagens por Augusto já se encontra em Viva vaia, nas séries intituladas Popcretos (1964-66), Equivocábulos (1970) e Profilogramas (1966-1974), nos poemas "olho por olho" (1964), "GOLDwEATER" (1964), "psiu!" (1966); "nada" (1970), "cicatristeza” (1970), "oeilfeujeu” (1970), "amortemor" (1970), "profilograma 2 (hom'cage to webern)” (1972), "sousândrade 1874-1974 (fotopsicograma)” (1974) e "janelas para pagu" (1974). Na quinzena seguinte o poeta năo utiliza fotografias em seus poemas. O recurso ausente em Despoesia coincide com a época de exploração de outros meios (letra-set, serigrafia, acrílico, holografia, laser, vídeo, computador, CD, performance). Dez anos depois, oútis será o único fotopoema de Não. Seu livro mais recente, Outro (2015) apresenta três novos: "destornado" (2005), "pessoanjos" (2010-2011) e "occhiocanto (ommagio a scelsi 2)" (2010). 
dois idiomas, às ideias de espectro, fantasma, imagem do morto e de cópia, duplo, simulacro, como metáfora do falso e do engano.

Do mesmo modo, onde se vê "grama", leia-se não apenas grámma, em grego, mas também, por metáfora e metonímia: verde, vida, relva de parque ou campo de cemitério. Como se diz de uma lápide coberta de musgo que o verde sobre a pedra significa a pátina do tempo acumulado sobre o morto, pode-se dizer que a grama cobrindo toda a imagem está ali para lembrar que olhamos para o chão, onde a relva nova cresce ao sol e onde se cavam as covas do passado. Fazendo o leitor coincidir com a sombra que passa, o jogo de olhares cruzados sobrepóe o ato de ler o texto, do leitor que olha a página, e o ato de ver a grama, da sombra que olha para o chão, de cabeça inclinada, em posição reflexiva, como quem lê um livro, convertendo toda a imagem em letra escrita.

Por fim, onde se vê "luz", leia-se phôs, que significa não apenas "luz do sol", "luz do dia", mas por extensão o próprio sol e toda forma de luz (das estrelas, da lua, do fogo, dos olhos...), sendo ainda uma metáfora para o olho e para a vida pública, "o que aparece" à luz e se manifesta na pólis, aos olhos de todos. Sem falar na longa tradiçáo filosófica da metáfora da luz como verdade e da sombra como mímesis ardilosa. Mas paralelamente também se pode ler o termo homônimo em grego phốs (com acento agudo em vez de perispômeno sobre o ômega), que significa: o "ser humano", homem ou mulher, designando especificamente sua condição de ser "mortal", por oposição aos deuses, cuja luz nunca se apaga.

Nesse arranjo, a sombra da direita assinalando a "ausência de sujeito" pode ser lida como a "sombra do poeta", enquanto metáfora visual do "poeta morto" (ficcionalizando uma situação de enunciação póstuma) ou do "poeta no limiar" (na condição de vivo-morto, a quem "tudo é permitido" em matéria de linguagem), duas metáforas particularmente caras a Augusto de Campos desde seu livro de estreia, como atestam os poemas "Diálogo a Um" ("Sou o Poeta, O que jaz, sendo vivo") e "O vivo" ("Não queiras ser mais vivo do que és morto"), ambos de $O$ Rei menos o reino (1951). Na verdade, desde antes, no primeiro poema de Augusto publicado em jornal, "Fuga", de 1948, os termos "sombra", "eco" e "rastro" se alternam significativamente como "figuras últimas do sujeito lírico", ficcionalizando uma comunicação que se tornou "inviável", como nota Sterzi (2004: 102), destacando nestes versos uma notável "consonância com poemas seus mais recentes, como 'morituro' (1994) e 'tour' (1999)", recolhidos em Não (2003): 


\section{Fuga}

Decepo as palavras

Esqueço as palavras

para sempre mortas.

Ausculto o silêncio:

Ainda tenho eco.

Corro sutilmente,

sabiamente voo

sem roçar areia.

Olho para trás:

ainda tenho rastro.

Me fecho no quarto

Revólver no ouvido

morro sem um grito.

Olho para o chão:

ainda tenho sombra. ${ }^{7}$

Após reaparecer em "salto" (1954), que abre a série Ovonovelo com a condicional "mesmo se morto" e introduz a palavra-valise "mumisepúltimo", observa Sterzi que "a figura do poeta morto passou para um segundo plano, tornou-se como que uma imagem secreta a pulsar sob os poemas, uma espécie de reserva de significação [...] mas também condição metafórica da enunciação" (2004: 104). Assim, no "desfácio" de Despoesia (1994) o autor dirá que "cada poema é como se fosse o último", e "níngua" (1993), do mesmo livro, escrito na "língua do não", convoca o poeta ainda vivo a corrigir essa falha: "morre / poeta chinfrim / xinga / a langue língua do sim [...] do poeta à míngua / morre/ e te vinga [...] singra / até o sem / sangra / até o fim / songa [...] para ninguém”.

Nesse sentido, pode-se dizer que a imagem da sombra que permanece no chão apesar de não haver mais alguém contra a luz, o "morto que faz sombra" no poema "fuga", retorna em oútis como uma "sombra de ninguém", sem corpo real que a produza. Suspendendo a relação tética com o referente, ela retorna como signo escrito, repetível, iterável, passível de ser lido e de produzir 
efeitos fora de contexto (Derrida), enquanto "ato de escrita" performativo despragmatizado (Iser).

Em vez de representar uma cena prévia e comunicar um referente anterior à linguagem, palavra e imagem convergem para uma cena fantasmática: ninguém escreve, ninguém faz sombra. Escrito e fotoscrito por ninguém, o texto na grama não visa nenhum leitor em particular ou, o que dá no mesmo, visa qualquer um. Elidindo o drama da "popularização da poesia", que ainda movia as vanguardas dos anos 1950-60 e agora promove a integraçáo do poeta ao mercado, por setorização (faixa de consumo) e circularidade (escrever para seus "iguais", supondo um acordo prévio quanto ao que se admite como "poesia"), oútis não faz concessão ao interesse ou ao gosto de ninguém. Marca de boa safra cabralina:

\author{
[...] e dificil- \\ mente se poderá dizer \\ com mais desdém, ou então dizer \\ mais direto ao leitor Ninguém \\ que o feito o foi para ninguém. \\ (João Cabral, "O artista inconfessável”)
}




\section{Referências}

AGUILAR, Gonzalo. "Algumas proposiçôes para se pensar a relação entre poesia e política na poesia concreta brasileira”. In: BANDEIRA, João; DE BARROS, Lenora. (org.) Poesia concreta: o projeto verbivocovisual. São Paulo: Artemeios, 2008.

ANDRADE, Mário de. A imagem de Mário - fotobiografia de Mário de Andrade. Rio de Janeiro: Alumbramento, 1998.

BENJAMIN, Walter. "A obra de arte na era de sua reprodutibilidade técnica". In: Obras escolhidas I: magia e técnica, arte e política. São Paulo: Brasiliense, 1996: 165-196.

BENJAMIN, Walter. "Pequena história da fotografia”. In: Obras escolhidas I: magia e técnica, arte e política. São Paulo: Brasiliense, 1996: 91-107.

CAMPOS, Augusto de. Viva vaia. Cotia, SP: Ateliê Editorial, 2001.

CAMPOS, Augusto de. Despoesia. São Paulo: Perspectiva, 1994.

CAMPOS, Augusto de. Não. São Paulo: Perspectiva, 2008.

CAMPOS, Augusto de. Outro. São Paulo: Perspectiva, 2015.

CAMPOS, Haroldo de. A arte no horizonte do provável. São Paulo: Perspectiva, 1977.

CAMPOS, A.; CAMPOS, H.; PIGNATARI, D. Mallarmé. Poemas. São Paulo: Perspectiva, 1974.

EISENSTEIN, Sergei. “O princípio cinematográfico e o ideograma”. In: CAMPOS, Haroldo. (org.) Ideograma. São Paulo: Ed.USP, 2000, p. 149-166.

SISCAR, Marcos. "A crise do livro ou a poesia como antecipação". In: STERZI, E. (org.) Do céu do futuro: cinco ensaios sobre Augusto de Campos. São Paulo: Marco, 2006, p. 115-135.

STERZI, Eduardo. “Todos os sons, sem som”. In: SÜSSEKIND, Flora; CASTAÑON, Júlio (orgs.) Sobre Augusto de Campos. Rio de Janeiro: 7Letras; Fundação Casa de Rui Barbosa, 2004, p. 95-115.

Thiago Castañon. Pesquisador do Programa de Pós-graduação em Letras Vernáculas da UFRJ, onde desenvolve o projeto de pós-doutorado "Mínima mímesis: a ruptura da lírica na poética de Augusto de Campos” (2019). Mestre em Teoria da Literatura (UFRJ, 2012) e Doutor em Teoria da Literatura (UFRJ, 2017). Organizou, junto com Aline Magalhães, a coletânea Escritos de véspera (Ed.UFSC, 2011), reunindo textos críticos e teóricos escritos por Luis Costa Lima nos anos 1970 e início de 1980.

E-mail: thiagocastanonloureiro@gmail.com 